\title{
Effectiveness of web based educational on improving knowledge of acne vulgaris self medication among senior high school students
}

\section{Efektivitas edukasi berbasis website terhadap pengetahuan remaja pada swamedikasi Acne vulgaris di SMA BOPKRI 2 Yogyakarta}

\author{
Lolita*, Ni Putu Isabela Meita Putri \\ Departemen Farmasi, Universitas Ahmad Dahlan \\ Jl. Prof. Dr. Soepomo, S.H., Janturan, Yogyakarta
}

\begin{abstract}
ABSTRAK
Kehadiran teknologi dapat menjadi alternatif dalam penyampaian edukasi terutama pada bidang kesehatan. Penelitian ini bertujuan untuk mengetahui efektivitas edukasi berbasis website terhadap pengetahuan remaja pada swamedikasi acne vulgaris di SMA BOPKRI 2 Yogyakarta. Penelitian ini merupakan experimental design dengan pre-test/post-test control group desain study. Kriteria inklusi pada penelitian ini yaitu siswa laki-laki maupun perempuan berumur 13-19 tahun, aktif dan dapat menggunakan media internet, serta bersedia mengisi kuesioner penelitian, sedangkan kriteria eksklusinya yaitu siswa yang melakukan perawatan kulit rutin dalam penanganan acne. Teknik pengambilan sampel menggunakan nonprobability sampling yaitu convenience sampling. Kelompok kontrol terdiri dari 62 responden yang diberi edukasi langsung dan menggunakan leaflet serta kelompok perlakuan terdiri dari 62 responden yang diberi edukasi langsung dan berbasis website (www.seputarfarmasi.com). Analisis data menggunakan uji student t-test untuk menilai pengaruh edukasi terhadap pengetahuan siswa. Uji independent $t$-test menunjukkan nilai $\mathrm{p}=0,000$ dimana terdapat peningkatan pengetahuan yang signifikan antara kelompok kontrol dengan perlakuan pada taraf kepercayaan 95\%. Penelitian ini menunjukkan bahwa edukasi berbasis website efektif dapat meningkatkan pengetahuan remaja mengenai swamedikasi acne vulgaris.
\end{abstract}

Kata kunci: acne vulgaris, remaja, website, pengetahuan

\begin{abstract}
The presence of technology can provide real alternatives to build knowledge in delivering health education materials. The aim of this study was to investigate if web-based education methods may rising a student's knowledge about self medication of acne. This research using an experimental pretest-posttest control group design while the sampling technique using convenience nonprobability sampling. Inclusion criteria for participants were senior high school students aged 13-19 years, active social media users, and willing to fill out the research questionnaire. Participants were allocated to the exclusion criteria as students who perform routine skin care in the acne treatment. Control group consisted of 62 respondents who were given face to face education and treatment group consisted of 62 respondents who were given website-based education. Data analysis were performed with a student t-test to assess the effect of educational intervention on student's knowledge.
\end{abstract}


The independent t-test showed there was a significant increase of knowledge between the control and the treatment groups $\quad(p=0,000)$ with $95 \%$ confidence level. This study demonstrate that web-based educational intervention had a significant increase on the student's knowledge about acne vulgaris self medication.

Keywords: acne vulgaris, adolescent, website, knowledge

\section{PENDAHULUAN}

Masa remaja merupakan masa perubahan dari masa kanak-kanak ke masa dewasa yang meliputi perubahan biologik, psikologik dan sosial. Riset pada remaja yang berjerawat dilaporkan bahwa sebagian besar cenderung memiliki masalah citra diri yang buruk, enggan berpartisipasi dalam kegiatan fisik, rendahnya kepercayaan diri serta kualitas hidup yang lebih buruk (Gunarsih, 2015). Survei di kawasan Asia Tenggara ditemukan 40-80\% kasus jerawat umumnya terjadi pada usia dewasa muda (14-17 tahun). Menurut catatan kelompok studi dermatologi kosmetika di Indonesia menunjukkan adanya peningkatan angka kejadian acne vulgaris dari 60\% pada tahun 2006 menjadi 80\% pada tahun 2007 (Andy, 2009).

Pertumbuhan pesat ilmu teknologi dan komunikasi menjadi salah satu pertimbangan dalam mengembangkan metode edukasi berbasis website (Hanley, 2006). Asosiasi Penyelengara Jasa Internet Indonesia melaporkan data bahwa pada tahun 2012 total pengguna internet di Indonesia telah mencapai 63 juta orang atau 24,23 persen dari total populasi. Angka ini semakin meningkat selama kurun waktu terakhir hingga saat ini. Adanya revolusi ini mengakibatkan pergeseran paradigma terhadap pemanfaatan media edukasi yang lebih interaktif dan mudah diakses (Yusuf, 2013).

Berangkat dari kenyataan diatas, maka farmasis berperan penting dalam mengedukasi remaja mengenai rasionalitas terapi penyakit khususnya acne vulgaris. Edukasi berbasis website sebagai metode edukasi alternatif yang merujuk pada profesi layanan kesehatan dalam pemanfaatan teknologi komunikasi internet (Amani, 2007). Teknologi ini mengacu pada kegiatan penyampaian informasi untuk mengikuti kebutuhan remaja sekarang (Hanley, 2006).

Saat memberikan edukasi berbasis website, farmasis dapat bertemu klien dengan bertatap langsung secara virtual melalui media internet. Hal ini sangat memudahkan farmasis dalam membantu klien terutama bagi remaja yang tidak terjangkau dalam hal jarak. Keuntungan lainnya dapat memperlancar interaksi farmasis dan remaja melalui media forum tanya jawab. Remaja bisa bertanya langsung secara personal perihal kasus penyakit serta terapi swamedikasi jerawat. Tujuan penelitian ini yaitu untuk mengetahui efektivitas edukasi berbasis website terhadap pengetahuan remaja pada swamedikasi acne vulgaris di SMA BOPKRI 2 Yogyakarta. Dengan adanya fasilitas pemberian edukasi melalui website, remaja dimudahkan dalam memperoleh informasi sehingga pengetahuan tentang penanganan penyakit pun akan meningkat.

\section{METODE PENELITIAN}

Metode yang digunakan pada penelitian ini adalah metode penelitian eksperimental dengan desain studi pre-test/post-test control group. Populasi pada penelitian ini berjumlah 302 orang dimana terdiri dari seluruh siswa kelas 10 dan 11 di SMA BOPKRI 2 Yogyakarta selama periode bulan Maret hingga April 2017. Lokasi dipilih karena akses yang mudah dijangkau peneliti. SMA ini juga memanfaatkan media internet sebagai forum aktif yang mengembangkan komunikasi guru dan peserta didik dalam memperoleh informasi kegiatan sekolah.

Sampel pada penelitian ini adalah siswa yang memenuhi kriteria inklusi, yaitu siswa laki-laki maupun perempuan yang berumur 13-19 tahun, aktif dan dapat menggunakan media internet, serta siswa yang bersedia mengisi kuisioner penelitian. Sedangkan kriteria eksklusi, yaitu siswa yang rutin melakukan kontrol ke dokter spesialis kulit atau melakukan perawatan rutin dalam penanganan acne vulgaris. 


\section{Instrumen dan Variabel Penelitian}

Instrumen yang digunakan dalam penelitian ini, yaitu:

Leaflet (lembar materi) dan website (www.seputarfarmasi.com)

Informasi-informasi yang terdapat dalam leaflet dan website yaitu pengertian swamedikasi, penjelasan mengenai acne vulgaris yang meliputi definisi, penyebab, proses terjadinya, jenis, usia, gejala, tempat terbentuk, penyebab, penyebaran, faktor pemicu, terapi swamedikasi baik farmakologi maupun non farmakologi, dan pencegahannya.

\section{Kuesioner}

Kuesioner diadaptasi dari kuesioner dalam skripsi yang berjudul "Pengetahuan dan Sikap Remaja SMA Santo Thomas 1 Medan Terhadap Jerawat" dan disusun oleh Andy pada tahun 2009 yang diuji kembali validitas dan reliabilitas kepada remaja di lokasi penelitian yang memenuhi kriteria inklusi dan eksklusi. Kuesioner yang digunakan yaitu kuesioner pengetahuan yang terdiri dari 13 soal dengan skor minimum sebesar 0 dan skor maksimum sebesar 36.

Variabel penelitian ini meliputi variabel bebas (edukasi tentang swamedikasi acne vulgaris dengan media website dan leaflet) dan variabel terikat (tingkat pengetahuan remaja tentang swamedikasi acne vulgaris).

\section{Prosedur Penelitian}

Penelitian ini menggunakan metode non-probability sampling yaitu convenience sampling dimana sampel diambil berdasarkan kelas yang diijinkan oleh pihak sekolah untuk dilakukannya penelitian. Pada penelitian ini diperoleh responden sebanyak 124 responden. Pada kelompok kontrol diperoleh sampel sebanyak 23 responden dari kelas 11 IPA I, 27 responden dari kelas 10 B, dan 12 responden dari kelas $10 \mathrm{~A}$. Pada kelompok perlakuan diperoleh sampel sebanyak 23 responden dari kelas 11 IPA II, 25 responden dari kelas $10 \mathrm{C}$, dan 14 responden dari kelas $10 \mathrm{~A}$.

Kelompok kontrol terdiri dari 62 responden yang diberi intervensi berupa edukasi menggunakan leaflet dan kelompok perlakuan terdiri dari 62 responden yang diberi intervensi berupa edukasi berbasis website. Kelompok kontrol dan perlakuan masing-masing dibagi menjadi 7-10 kelompok dimana setiap kelompok terdiri dari 6-8 orang. Kelompok kontrol dan perlakuan masing-masing akan diberi intervensi pada hari yang berbeda namun dalam satu waktu. Selama pemberian edukasi, masingmasing kelompok diberikan kesempatan untuk berdiskusi sesama rekan satu grup dan aktif bertanya kepada peneliti sehingga edukasi berjalan interaktif dua arah. Untuk mengukur skor pengetahuan sebelum dan sesudah edukasi, digunakan alat bantu berupa kuisioner pengetahuan yang sudah diuji terlebih dahulu validitas dan reliabilitasnya.

\section{Proses pengambilan data yang dilakukan, yaitu:}

Pre-test

Pengambilan data dilakukan sebelum responden memperoleh intervensi berupa edukasi mengenai swamedikasi acne vulgaris (pre-test).

\section{Edukasi}

Edukasi pada penelitian ini dilakukan setelah pelaksanaan pre-test. Pada penelitian ini, edukasi dilakukan dengan pemberian leaflet pada kelompok kontrol, sedangkan pada kelompok perlakuan diberikan edukasi dengan media berbasis website (www.seputarfarmasi.com).

Post-test edukasi.

Merupakan pengambilan data yang dilakukan setelah 1 hari responden memperoleh pemberian

\section{Analisis Data}

Analisis data dimulai dengan menghitung nilai dari pertanyaan kuesioner tingkat pengetahuan yang dijawab dengan tepat oleh responden baik pada pre-test maupun post-test. Seluruh data yang diperoleh selanjutnya dianalisis dengan program SPSS For Windows 16.0. Adapun analisis yang dilakukan sebagai berikut (Santoso,2010) : 


\section{Uji normalitas}

Uji normalitas dilakukan dengan teknik analisis statistik Kolmogorov-Smirnov. Tujuan dari uji normalitas adalah untuk mengetahui apakah sebaran data hasil penelitian mengikuti distribusi normal. Data dikatakan terdistribusi normal jika hasil analisis menunjukan nilai $p>0,05$. Apabila data terdistribusi normal, maka dilakukan analisis data menggunakan analisis parametrik. Jika data tidak terdistribusi normal, maka analisis data menggunakan uji non parametrik.

\section{Uji t-berpasangan (paired t-test)}

Uji t-berpasangan digunakan untuk melihat perbedaan antara total nilai responden sebelum dan sesudah mendapatkan edukasi baik pada kelompok kontrol maupun kelompok perlakuan. Hasil analisis dikatakan terdapat perbedaan yang signifikan antara pre-test dengan post-test apabila diperoleh nilai $p<0,05$. Uji alternatif bila syarat uji parametrik tidak terpenuhi adalah dengan uji Wilcoxon.

\section{Independent t-test}

Uji independent t-test digunakan untuk melihat perbedaan selisih nilai pre-test dan post-test pada kelompok kontrol dan kelompok perlakuan. Hasil analisis dikatakan terdapat perbedaan yang signifikan antara kelompok kontrol dengan kelompok perlakuan apabila diperoleh nilai $p<0,05$. Uji alternatif bila syarat uji parametrik tidak terpenuhi adalah dengan uji Mann Whitney.

\section{One Way ANOVA (ANOVA satu jalur)}

Uji One Way ANOVA digunakan untuk melihat perbedaan antara total nilai variabel terikat dengan karakteristik responden yang memiliki 3 atau lebih kelompok, baik pada kelompok kontrol maupun kelompok perlakuan. Hasil analisis dikatakan terdapat perbedaan yang signifikan antara total nilai variabel terikat dengan karakteristik responden apabila diperoleh nilai $p<0,05$. Uji alternatif bila syarat uji parametrik tidak terpenuhi adalah dengan uji Kruskal Wallis.

\section{HASIL DAN PEMBAHASAN}

Berdasarkan uji validitas dan reliabilitas yang telah dilakukan peneliti sebanyak 2 kali diperoleh nilai $r$ hitung $>r$ tabel $(0,361)$ pada keseluruhan soal pada kuesioner pengetahuan. Sedangkan pada uji reliabilitas, keseluruhan kuesioner dinyatakan reliabel dengan nilai Cronbach's Alpha>600.

\section{Gambaran karakteristik responden}

Usia responden pada penelitian ini berkisar 14-18 tahun. Berdasarkan hasil penelitian, usia responden pada kelompok kontrol sebesar 16,10 $\pm 0,674$ tahun dan pada kelompok perlakuan sebesar $16,05 \pm 0,838$ tahun. Hal tersebut menunjukkan bahwa pada usia 16 tahun merupakan rentang usia remaja dengan prevalensi tertinggi terjadinya jerawat (Notoadmodjo, 2007; Andy, 2009). Menurut Lynn et al., (2016), acne vulgaris merupakan salah satu penyakit yang sering timbul pada masa remaja di masa awal pubertas. Pada masa pubertas terjadi kenaikan hormon androgen yang beredar dalam darah dan menyebabkan hipersekresi dari glandula sebasea sehingga memicu timbulnya acne vulgaris. Sebaran data terhadap rata-rata usia responden dapat dilihat pada Tabel I.

Tabel I. Karakteristik responden berdasarkan usia

\begin{tabular}{ccc}
\hline Usia & $\begin{array}{c}\text { Kelompok } \\
\text { Kontrol }\end{array}$ & $\begin{array}{c}\text { Kelompok } \\
\text { Perlakuan }\end{array}$ \\
\hline$(\mathrm{x}+\mathrm{SD})$ & $16,10 \pm 0,694$ & $16,05 \pm 0,838$ \\
\hline
\end{tabular}

Berdasarkan jenis kelamin, responden laki-laki pada kelompok kontrol $(65 \%)$ lebih banyak daripada perempuan (35\%). Begitu pula pada kelompok perlakuan, persentase responden laki-laki lebih tinggi dibanding perempuan. Hal ini sesuai dengan teori dimana prevalensi tertinggi terjadinya jerawat adalah pada laki-laki yaitu berkisar $95-100 \%$ dibanding perempuan berkisar $83-85 \%$ (Fulton, 2010). Hal ini dapat timbul karena adanya faktor pencetus jerawat seperti makanan dan stress. Lakilaki cenderung terlambat untuk mencari pengobatan acne vulgaris dan lebih memilih untuk membiarkan keluhan kemudian baru datang berobat jika kondisi sudah parah (Ayudianti dan 
Indramaya, 2014). Sebaran data terhadap persentase jenis kelamin responden dapat dilihat pada Tabel II.

Tabel II. Karakteristik responden berdasarkan jenis kelamin

\begin{tabular}{ccccc}
\hline Jenis & \multicolumn{2}{c}{ Kelompok Kontrol } & \multicolumn{2}{c}{ Kelompok Perlakuan } \\
\cline { 2 - 5 } Kelamin & Jumlah & Persentase & Jumlah & Persentase \\
\hline Laki-laki & 40 & $65 \%$ & 33 & $53 \%$ \\
Perempuan & 22 & $35 \%$ & 29 & $47 \%$ \\
Total & 62 & $100 \%$ & 62 & $100 \%$ \\
\hline
\end{tabular}

Berdasarkan jenis transportasi sekolah, responden pada kelompok kontrol yang diberikan edukasi langsung dengan leaflet lebih banyak menggunakan motor sebagai transportasi utama ke sekolah (77\%). Begitu pula pada kelompok perlakuan yang diberikan edukasi berbasis website dengan persentase sebesar $79 \%$. Terlalu sering berada di lingkungan yang banyak debu, kotor dan terpapar asap kendaraan bermotor akan membuat wajah menjadi kotor. Jika tidak rajin membersihkan wajah, debu dan kotoran akan menumpuk dan menyumbat pori-pori sehingga mengakibatkan jerawat (Achroni, 2012). Sebaran data terhadap persentase transportasi sekolah responden dapat dilihat pada Tabel III.

Tabel III. Karakteristik responden berdasarkan transportasi sekolah

\begin{tabular}{ccccc}
\hline Transportasi & \multicolumn{2}{c}{ Kelompok Kontrol } & \multicolumn{2}{c}{ Kelompok Perlakuan } \\
\cline { 2 - 5 } Sekolah & Jumlah & Persentase & Jumlah & Persentase \\
\hline Jalan Kaki & 4 & $7 \%$ & 3 & $5 \%$ \\
Sepeda & 0 & $0 \%$ & 1 & $2 \%$ \\
Motor & 48 & $77 \%$ & 49 & $79 \%$ \\
Mobil & 5 & $8 \%$ & 2 & $3 \%$ \\
Angkutan Umum & 5 & $8 \%$ & 7 & $11 \%$ \\
Total & 62 & $100 \%$ & 62 & $100 \%$ \\
\hline
\end{tabular}

\section{Edukasi leaflet dan website terhadap peningkatan skor pengetahuan}

Pada kelompok kontrol dengan edukasi leaflet dan kelompok perlakuan dengan edukasi berbasis website, diperoleh rata-rata peningkatan skor pengetahuan sebelum dan sesudah diberikan edukasi seperti terlihat pada Tabel IV.

Tabel IV. Rata-rata skor pengetahuan sebelum dan sesudah edukasi leaflet dan website

\begin{tabular}{|c|c|c|}
\hline Rata-rata Skor & Leaflet & Website \\
\hline$(x+S D)$ & $7,08 \pm 5,224$ & $11,27 \pm 4,979$ \\
\hline $\begin{array}{c}p \text { value } \\
\text { (Uji normalitas) }\end{array}$ & 0,200 & 0,200 \\
\hline $\begin{array}{c}p \text { value } \\
\text { (Uji independent } t \text {-test) }\end{array}$ & \multicolumn{2}{|c|}{0,000} \\
\hline
\end{tabular}

Berdasarkan Tabel IV, rata-rata perubahan skor pengetahuan responden sebelum dan sesudah diberikan edukasi secara langsung dengan leaflet pada kelompok kontrol sebesar $(7,08 \pm 5,224)$ sedangkan rata-rata perubahan skor pengetahuan responden sebelum dan sesudah diberikan edukasi berbasis website sebesar $(11,27 \pm 4,979)$. Dilihat dari rata-rata perubahan skor pengetahuan sebelum dan sesudah edukasi pada tiap kelompok, diperoleh peningkatan rata-rata skor pengetahuan sebesar $4,19 \pm 0,245$. 
Pada uji normalitas diperoleh $p$ value sebesar 0,200 terhadap rata-rata peningkatan skor pengetahuan sebelum dan sesudah edukasi yang menunjukkan bahwa data tersebut terdistribusi normal. Uji independent $t$ test diperoleh $p$ value sebesar 0,000 yang menunjukkan bahwa terdapat perbedaan yang signifikan terhadap rata-rata peningkatan skor pengetahuan sebelum dan sesudah edukasi langsung berbasis leaflet dan website.

Sejalan dengan hasil penelitian Erviana et al., (2012) diperoleh bahwa mayoritas responden yang diedukasi dengan media leaflet memiliki tingkat pengetahuan cukup sehingga media leaflet kurang efektif dalam meningkatkan pengetahuan. Leaflet adalah media penyuluhan yang berfungsi dalam mempermudah penerimaan pesan. Leaflet dipilih sebagai media edukasi karena mudah disimpan, ekonomis dan bisa berfungsi sebagai pengingat bagi sasaran. Keberhasilan penyuluhan dapat dilihat dari peningkatan pengetahuan (Pulungan, 2008).

Skor pengetahuan responden yang diberikan edukasi berbasis website lebih tinggi dibanding leaflet. Hal ini menunjukkan bahwa edukasi berbasis website lebih baik dibanding leaflet. Hasil penelitian ini sejalan dengan penelitian Tuong et al., (2015) dimana terdapat perbedaan pengetahuan yang signifikan $(\mathrm{p}=0,002)$ antara edukasi berbasis website tentang acne vulgaris dengan edukasi media lain. Tuong et al., (2015) juga berpendapat bahwa jumlah kunjungan situs website berkorelasi positif dengan peningkatan pengetahuan dimana materi pendidikan mengenai acne vulgaris lebih bermanfaat dan lebih menyenangkan di kalangan remaja. Sesuai dengan penyataan Sunarto (2010), layanan edukasi online merupakan layanan yang dapat diberikan kepada masyarakat luas sehingga memberikan kemudahan dalam mengakses informasi. Pengetahuan masyarakat tentang berbagai informasi dapat diperoleh dengan mudah melalui internet terutama website. Masyarakat akan mendapatkan informasi tentang suatu kejadian yang ingin diketahuinya. Seiring dengan perkembangan teknologi yang semakin pesat, penggunaan internet semakin meningkat karena memiliki beberapa keunggulan dibanding media lainnya. Salah satunya website lebih cepat dalam menyajikan informasi, praktis, dan fleksibel karena dapat diakses darimana dan kapan saja (Yohan, 2013).

Media leaflet merupakan bentuk penyampaian informasi kesehatan melalui lembaran yang dilipat. Isi informasi dapat dalam bentuk kalimat maupun gambar atau kombinasi, namun kesederhanan penyajian pada leaflet membuat remaja lebih tertarik dalam mencari informasi melalui media internet (Gani et al., 2014).

\section{Karakteristik responden terhadap perubahan skor pengetahuan pada edukasi berbasis leaflet dan website}

Berdasarkan hasil penelitian, pada kelompok kontrol dengan edukasi langsung dan menggunakan leaflet maupun pada kelompok perlakuan dengan edukasi langsung dan berbasis website diperoleh $p$ value sebesar 0,000 dimana datanya dapat dilihat pada Tabel $\mathrm{V}$

\section{Tabel V. Rata-rata peningkatan skor pengetahuan terhadap edukasi leaflet dan website berdasarkan usia}

\begin{tabular}{lcc}
\hline \multirow{2}{*}{ Usia } & Leaflet & Website \\
\cline { 2 - 3 } & $p$ value (Uji Mann Whitney) \\
\hline 14-18 tahun & 0,000 & 0,000 \\
\hline
\end{tabular}

Tabel V menunjukkan bahwa terdapat perbedaan yang signifikan terhadap tingkat pengetahuan dengan usia responden. Hasil penelitian ini berbeda dengan penelitian Andy (2009) dimana tidak terdapat perbedaan yang signifikan dari tingkat pengetahuan responden berdasarkan rentang usia pada remaja. Menurut Anggraini (2012), masalah jerawat memberi kesan psikologis yang buruk pada remaja, terutama remaja dalam rentang usia sekolah. Remaja yang mengalami masalah jerawat seringkali mempunyai masalah yang berkaitan dengan kepercayaan diri. Individu yang mempunyai kepercayaan diri memiliki perasaan positif terhadap dirinya, punya keyakinan kuat dan pengetahuan 
akurat terhadap kemampuan yang dimiliki sehingga usia dapat mempengaruhi pengetahuan remaja terhadap jerawat (Purwanti, 2013).

Berdasarkan data di Tabel VI, pada kelompok kontrol diperoleh $p$ value sebesar 0,282, sedangkan kelompok perlakuan diperoleh $p$ value sebesar 0,949 dengan uji Kruskal Wallis. Hal ini menunjukkan bahwa tidak terdapat perbedaan yang signifikan terhadap tingkat pengetahuan dengan jenis kelamin.

Tabel VI. Rata-rata peningkatan skor pengetahuan terhadap edukasi Leaflet dan Website berdasarkan jenis kelamin

\begin{tabular}{ccc}
\hline Jenis Kelamin & $\begin{array}{l}\text { Leaflet } \\
\text { p value (Uji Kruskal Wallis) }\end{array}$ \\
\hline $\begin{array}{c}\text { Laki-laki } \\
\text { Perempuan }\end{array}$ & 0,282 & $\begin{array}{c}\text { Website } \\
0,949\end{array}$ \\
\hline
\end{tabular}

Hasil ini sejalan dengan penelitian Al Hoqail (2003) dimana jenis kelamin tidak berpengaruh terhadap tingkat pengetahuan responden tentang jerawat. Peneliti berasumsi bahwa informasi yang diperoleh remaja tidak dipengaruhi jenis kelamin namun bagaimana kemauan pribadi remaja untuk mengetahui dan menggali informasi tentang swamedikasi acne vulgaris.

Tabel VII menggambarkan rata-rata peningkatan skor pengetahuan sebelum dan sesudah diberikan edukasi pada tiap kelompok berdasarkan transportasi sekolah. Berdasarkan data penelitian pada kelompok kontrol diperoleh $p$ value sebesar 0,563 dan kelompok perlakuan diperoleh $p$ value 0,562 dengan uji Kruskal Wallis. Hal ini menunjukkan bahwa tidak ada perbedaan yang signifikan terhadap tingkat pengetahuan ditinjau dari perbedaan jenis transportasi sekolah.

\section{Tabel VII. Rata-rata peningkatan skor pengetahuan terhadap edukasi leaflet dan website} berdasarkan transportasi sekolah

\begin{tabular}{ccc}
\hline Transportasi & $\begin{array}{l}\text { Leaflet } \\
\text { p value (Uji Kruskal Wallis) }\end{array}$ \\
\hline Jalan Kaki & & Website \\
Sepeda & & \\
Motor & 0,563 & 0,562 \\
Mobil & & \\
Angkutan Umum & & \\
\hline
\end{tabular}

Peneliti berasumsi bahwa pengetahuan remaja mengenai swamedikasi acne vulgaris tidak berdasarkan pada transportasi yang digunakan saat bersekolah. Meskipun remaja sering berada di lingkungan yang banyak debu, kotor, dan terpapar asap kendaraan, jika remaja lebih mengetahui mengenai swamedikasi dan upaya pencegahan terjadinya Acne vulgaris, maka remaja dapat meminimalisir kemungkinan timbulnya jerawat (Achroni, 2012).

\section{KESIMPULAN}

Berdasarkan hasil penelitian dapat disimpulkan bahwa edukasi berbasis website pada swamedikasi acne vulgaris lebih efektif dibandingkan edukasi media leaflet dengan perbedaan yang signifikan $(\mathrm{p}=0,000)$ terhadap rata-rata perubahan skor pengetahuan sebelum dan sesudah edukasi. Untuk penelitian selanjtunya diharapkan dapat memperluas lokasi penelitian pada beberapa sekolah di wilayah yang lebih luas. Disamping itu perlu dilakukan penelitian serupa pada jenis penyakit lainnya menggunakan media edukasi berbasis website dengan melihat pengaruhnya pada variabel seperti sikap, perilaku dan lain-lain. Ke depan metode edukasi berbasis website dapat menjadi alternatif utama dalam praktek layanan kefarmasian kepada pasien. 


\section{DAFTAR PUSTAKA}

Achroni, K., 2012, Semua Rahasia Kulit Cantik dan Sehat Ada disini, 23-26, Javalitera, Yogyakarta.

Al Hoqail, I.A., 2003, Knowledge, Beliefs and Perceptions of Youth Toward Acne Vulgaris, Saudi Med J, 24: 765-768.

Amani, N., 2007, Investigating The Nature, The Prevalence, and Effectiveness of Online Counselling, Thesis, Department of Educational Psychology Administration and Counselling California State University, Long Beach.

Andy, 2009, Pengetahuan dan Sikap Remaja SMA Santo Thomas 1 Medan Terhadap Jerawat, Skripsi, Fakultas Kedokteran Universitas Sumatra Utara, Medan.

Anggraini D., 2012, Hubungan Gambaran Diri dengan Interaksi Sosial pada Remaja yang Berjerawat, Skripsi, Fakultas Keperawatan, Universitas Andalas, Padang.

Ayudianti, P., Indramaya, D.M., 2014, Study Retrospektif: Faktor Pencetus Akne Vulgaris, Berkala Ilmu Kesehatan Kulit dan Kelamin-Periodical of Dermatology and Venereology, 26(1).

Erviana, N.W., Mansur, H., Yudianti, I., 2012, Efektifitas Penyuluhan Menggunakan Media Leaflet dan Video Terhadap Pengetahuan Remaja Putri Tentang Aborsi, Laporan Penelitian, Poltekkes Kemenkes Malang.

Fulton, J., 2010. Acne vulgaris in Medscape Journal; Available from: http://dermatology.cdlib.org/ 93/commentary/acne/hanna.html.

Gani, H.A., Istiaji, E., Kusuma, A.I.,2014, Perbedaan Efektifitas Leaflet dan Poster Produk Komisi Penanggulangan AIDS Kabupaten Jember dalam Perilaku Pencegahan HIV/AIDS, Skripsi, Fakultas Kesehatan Masyarakat, Universitas Jember, Jember.

Gunarsih, S., 2015, Hubungan Antara Jerawat Dengan Citra Diri Pada Remaja Putri di SMA Negeri 4 Semarang, Skripsi, Fakultas Ilmu Keperawatan dan Kesehatan Universitas Muhammadiyah Semarang, Semarang.

Hanley, T., 2006, Developing Youth-Friendly Online Counselling Services in the United Kingdom: A Small Scale Investigation into the Views of Practitioners, Counselling and Psychotherapy Research, 6(3): 182-185.

Lynn, D.D., Umari, T., Dunnick, C.A., Dellavalle, R.P., 2016, The Epidemiology of Acne Vulgaris in Late Adolescence, Dove Press Journal : Adolescent Health, Medicine and Therapeutics, 7:1325.

Notoatmodjo, S., 2007, Promosi Kesehatan Teori dan Aplikasi, P.T. Rineka Cipta, Jakarta.

Pulungan, R., 2008, Pengaruh Metode Penyuluhan Terhadap Peningkatan Pengetahuan dan Sikap Dokter Kecil dalam Pemberantasan Sarang Nyamuk Demam Berdarah (PSN-DBD) di Kecamatan Helvetia Tahun 2007, Tesis, Universitas Sumatera Utara, Medan.

Purwanti, S.P., 2013, Mengatasi Masalah Kepercayaan Diri Siswa Melalui Layanan Konseling Kelompok, Skripsi, Fakultas Ilmu Pendidikan, Universitas Negeri Semarang, Semarang.

Santoso, S., 2010, Statistik Multivariat, P.T. Elex Media Komputindo, Jakarta.

Sunarto, M., 2010, Konseling HIV Online Berbasis Internet, Laporan, Fakultas Ilmu Keperawatan Universitas Indonesia.

Tuong, W., Wang, A.S., Armstrong, A.W., 2015, Comparing The Effectiveness of Automated Online Counseling to Standar Web-Based Education on Improving Acne Knowledge: a Randomized Controlled Trial, Am J Clin Dermatol, 16(1): 55-60.

Yohan, 2013, Pengaruh Terpaan Media Online Detik.com Terhadap Tingkat Pengetahuan Umum Karyawan Mara Advertising Yogyakarta, Skripsi, Fakultas Ilmu Sosial dan Ilmu Politik, Universitas Atma Jaya Yogyakarta, Yogyakarta.

Yusuf, 2013, Pengguna Internet Indonesia Bisa Tembus 82 juta, Tekno Kompas, http;//tekno.kompas.com/read/2012/12/13/101023065/2013.pengguna.internet.indonesia.bisa.tem bus.82.juta. 